\title{
Kirkeindsigt og udsyn - kommune og folkekirke
}

Marie Vejrup Nielsen

Lektor, ph.d., Religionsvidenskab, Institut for Kultur og Samfund, Aarhus Universitet

Artiklen analyserer eksempler på konkrete interaktioner mellem folkekirken og kommune ud fra et 'governance'-perspektiv, der lægger vægt på, hvilke aktører og strukturer der former forholdet mellem religiøse grupper og samfundet. De eksempler, der analyseres, er hentet fra tre former for beskyttelse af folkekirkens bygninger: kirkeindsigten, kirkebyggelinjen og kirkeomgivelsesfredningen. Ud fra eksemplerne diskuterer artiklen folkekirkens position i forhold til lokale myndigheder.

Der er ofte fokus på de store værdipolitiske spørgsmål, når forholdet mellem religion og politik er på dagsordenen. Det er spørgsmål, som umiddelbart springer i øjnene, som noget 'der har med religion at gøre', såsom muslimske tørklæder eller religiøse spiseregler i forhold til folkeskole og institutioner. Dette gælder også, når fokus er på forholdet mellem den danske folkekirke og stat og samfund, som det kunne ses af debatten om indførslen af vielser af homoseksuelle i folkekirken i 2013. Der er i forskningen sjældent fokus på det lokale, men mere på det nationale eller internationale niveau, når det gælder spørgsmål om religion og politik, såsom undersøgelser af politiske partiers holdninger til religion, lovgivning på områder, der berører religion og undersøgelser af tendenser i offentlig debat om disse emner. I de tilfælde, hvor der i forskningen er interesse for det lokale perspektiv i forhold til religion og politik, er det primært minoritetsreligioner, der er i fokus. Denne artikel vil se nærmere på et anonymt, lokalt møde mellem politik og religion ved at analysere konkrete eksempler på, hvordan kommunen administrerer generel lovgivning på områder, hvor det største trossamfund i Danmark i dag, folkekirken, bliver berørt. Artiklen ser ikke på folkeskole- og børneinstitutionsområdet, selvom dette er et interessant felt, særligt efter indførslen af sko- lereformen vedtaget i 2013. Artiklen ser heller ikke på spørgsmålet om opførslen af religiøse bygninger, som er et andet berøringsfelt mellem religiøse grupper og kommunen. Målet med denne artikel er netop ikke at se på forandringer eller værdipolitiske mærkesager. Der er i stedet tale om en undersøgelse af de mere anonyme konsekvenser af den politiske styring af forskellige områder på lokalt plan. Derfor er alle cases udvalgt fra konkrete institutionelle mødesteder mellem folkekirke og kommune i form af forvaltning af lovmæssig beskyttelse af folkekirkens kirkebygninger: kirkeindsigten, kirkebyggelinjen og kirkeomgivelsesfredning. Artiklen peger i sin konklusion på, at det primært er generelle overvejelser om kulturarv, som styrer beslutninger i disse cases, og ikke spørgsmål om kirkens selvforståelse eller behov. Kommunerne ser i disse sager ikke på folkekirken som et trossamfund, men som en aktør involveret i spørgsmål om kulturarv.

\section{Kommunal håndtering}

I forskningen i forholdet mellem religion og politik spiller sekulariseringsteorier og perspektiver en stor rolle som en overordnet ramme for at forstå de forandringer, der sker internationalt, såvel som i en dansk sammenhæng (Dobbelaere 1981, Kühle 1999, Bruce 2002, Kühle og Nielsen 2011). Og der er i stigende grad fokus på, hvordan forholdet mellem religion og samfund fremstilles i forskellige kontekster i form af såkaldte sekularismer (Calhoun 2011, Reintoft Christensen 2014). Denne artikel er i tråd med denne udvikling, idet den vil identificere konkrete måder, hvorpå religion håndteres i en politiskadministrativ sammenhæng. Artiklen vil primært tage udgangspunkt i det såkaldte governance-perspektiv for at sætte fokus på de aktører og praksisformer, der tegner sig inden for konkrete lovgivningsmæssige rammer. Governance-perspektivet indgår $i$ en lang række forskningssammenhænge (Torfing, Peters, Pierre og Sørensen 2012). I denne artikel vil der primært være fokus på en 
tilgang, som direkte har beskæftiget sig med spørgsmålet om trossamfund. Politologen Marcel Maussen beskriver i sin oversigtsartikel om 'governance' formålet med perspektivet som et ønske om at kunne forstå de processer, hvormed et samfund sætter rammerne for udviklingen af islam i en europæisk sammenhæng:

\section{Introducing the concept governance in studies on the accommodation of Islam also creates opportunities for a type of analysis that goes beyond the study of (formal) legal arrangements, and also looks at practices of application, implementation and interpreta- tion. It includes the systematic study of customs, conventions and agreements that result in specific forms of regulation, and it widens the scope of actors and institutions that might be involved in one way or the other in the actual accommodation of Islam in Europe. (Maussen, 2006, 5)}

I denne brug afgovernance-perspektivet er der ofte et fokus på lokale og regionale kontekster, hvor religion håndteres, f.eks. i studier af, hvordan lokale sammenhænge påvirker organiseringen af muslimer, f.eks. igennem nedsættelse af råd med religiøse repræsentanter og regulering af påklædning og fødevarer (Maussen, 2006). Maussen har i sin tilgang udelukkende fokus på islam og spørgsmålet om tilpasning (accommodation) mellem samfund og diverse aktører fra muslimske sammenhænge. Men indsigterne fra Maussens perspektiv kan med fordel benyttes på undersøgelser af majoritetsreligion og særligt de etablerede, historiske kirker. Maussen fremhæver, at netop forholdet mellem stat og kirke er med til at danne de rammer inden for hvilke et samfund regulerer religion (Maussen 2006, 22; 51-54; 63). Der er således i et samfund allerede dannet en model for, hvordan stat og/eller andre aktører håndterer religion og denne håndteringsmodel er baseret på den historiske udvikling, der har været mellem stat og religion i et givent område, i en europæisk sammenhæng vil det ofte være de store historiske kirker. Argumentet i denne artikel er, at de store historiske kirker, som folkekirken, ikke kun er en del af den model for religion, som allerede er etableret. Selvom et historisk kirkesamfund er en integreret del af et samfund og en stat, så udelukker det ikke, at den som selvstændig institution påvirkes af de logikker, som staten eller andre niveauer af forvaltning og håndtering styres af, tværtimod. Også de store kirkesamfund skal navigere $\mathrm{i}$ et moderne, sekulariseret politisk system, og også kirker med tætte bånd til staten kan komme i situationer, hvor kirken bliver en selvstændig aktør med andre interesser end den offentlige forvaltning.
Det er netop eksempler på dette, som denne artikel vil se nærmere på. I forlængelse af disse spørgsmål kan man også overveje, om den lokale, kommunale praksis på sigt kan påvirke det nationale niveau, så udviklingen ikke primært skal ses oppefra og ned i det offentlige system, men at også erfaringer og praksisformer på det lokale niveau på sigt kan ændre de mere overordnede forhold. Det ligger uden for denne artikels sigte at undersøge dette, men det kan f.eks. overvejes, om lokale sognekirker og stifters erfaringer med at skulle navigere mere som selvstændige aktører over for offentlig forvaltning på sigt kan være med til at danne baggrund for et ønske om en større grad af afklaring af forholdet mellem stat og kirke i fremtiden.

\section{Folkekirken lokalt}

Folkekirken er en institution, som har udviklet sig sammen med staten, og som har rødder tilbage i den form for institutionalisering af religion, som i Danmark særligt skete igennem reformationen, hvor kirken blev lagt under kongen. Og med indførslen af enevælden i $1660 \mathrm{blev}$ der tale om en kirke, som var knyttet tæt til kongemagten. Med grundloven i 1849, alle debatter og konflikter ufortalt, transformeres kirken fra en kongekirke til en folkekirke og udvikler sig i takt med samfundet igennem Folketingets løbende lovgivningsarbejde og kirkeministerens ledelse. Folkekirkens institutionelle struktur har to primære ledelsesformer, som begge er kendetegnet ved en demokratisk valgt ledelse. Folketinget, regering og kirkeministeren er øverste ledelse i kirken baseret i det almene, parlamentariske demokrati, og menighedsrådet er den lokale ledelse af kirken på sogneniveau, valgt gennem internt medlemskabsbaseret demokrati. ${ }^{1}$ Provster og biskopper vælges også ved valg baseret på indre kirkelige strukturer. Folkekirken i Danmark adskiller sig institutionelt fra de fleste andre store historiske kirker ved ikke at have et selvstændigt, nationalt repræsentationsniveau i form af et kirkeråd eller en synode (Kühle og Nielsen 2011). Folkekirken er en del af det generelle, danske administrative system igennem varetagelsen af civilregistreringsopgaver, såsom registrering af alle nyfødte i Danmark. Og derudover er der en lang række formelle og uformelle bånd mellem den danske stat, det danske samfund og folkekirken, som følge af den historiske udvikling og som i dag fortsætter i en forholdsvis stabil udvikling, hvor 78,4\% af den danske befolkning er medlem af folkekirken. Denne kirkelige struktur og særligt sognestrukturen vil blive inddraget her, fordi spørgsmålet er, om sognet er synligt som kerneaktør i forhold til kommunerne, og fordi der er dimensioner ved sognestrukturen, som er interessante i forhold til spørgsmålet om, hvad der er på spil i forholdet mellem religion og politik på kommunalt niveau. 
Den grundlæggende strukturelle enhed i folkekirken er sognet. Sognet er samtidig en central enhed i strukturen i det danske samfund. Sognestrukturen i Danmark går langt tilbage som en administrativ inddeling af landet, og denne inddeling er fulgt med igennem store ændringer inden for religion og inden for det danske samfund generelt. Registrering og kontrol med borgerne gik tidligere igennem sognet og sognets religiøse leder, præsten. Denne udvikling kan f.eks. ses i indførslen af konfirmationen i Danmark i 1736, som afspejler sammenfaldet mellem religion og civile rettigheder, idet man skulle være konfirmeret for at kunne opnå fuld samfundsdeltagelse som voksen, dvs. for at kunne blive gift eller eje ejendom.

Sognet er en central kirkelig enhed, hvor folkekirken er tættest på sine medlemmer, og denne nærhed er i en dansk sammenhæng blevet knyttet til først kongemagtens og siden det moderne parlamentariske styres administration og håndtering af borgerne. Sognestrukturen er også i forskningen blevet fremhævet som noget, der har relevans for forståelse af det danske samfunds udvikling. I et historisk perspektiv er der blevet peget på sognestrukturen som en faktor i udviklingen af det danske samfund generelt, det vil sige som en faktor i udviklingen også af den politiske dimension af det danske samfund. Sognepræsten har også haft en særlig rolle, som har forbundet kirke og stat på det lokale niveau, igennem en række fødte medlemsskaber af ledelse af det der senere bliver kommunen i forskellige funktioner. Og selvom sognepræsten i landkommunalreformen i 1855 mister denne faste plads i sogneforstanderskabet, indgår han fortsat i forvaltning af fattig- og skolevæsen. Denne position ændres i 1867, da sognerådene etableres, men præsten er fortsat født medlem af skolekommissionen indtil reformen i 1933, hvor præster mister deres ret til tilsyn med det landkommunale skolevæsen (Clemmensen 2011). ${ }^{2}$ Der er også hos en række forskere fokus på sammenhængen mellem organisering af kirken og udviklingen af det moderne samfund, hos Østergaard og Knudsen med et specifikt sigte på udviklingen af velfærdsstaten (Sidenvall 2011, Østergaard 2003, Knudsen 2003).

Det vil sige, at ikke alene er denne lokale dimension central for kirken, som ramme for det religiøse liv i sognet, men den er også en ramme omkring det lokale samfund og udgør et element i hele samfundets struktur og sammenhæng. Denne tanke går igen i forskningssammenhænge, som slet ikke knytter sig til religionsfaglige eller historiske miljøer:

Et sogn er i sin oprindelse betegnelsen for et område med en fælles kirke. De danske sogne udgjorde frem til kommunalreformen i 1970 på landet normalt også en selvstændig kommune (sognekommune), idet mange kommuner dog bestod af 2 eller 3 sogne. Endnu i dag følger kommunegrænser og skoledistrikter på landet oftest sognegrænserne, ligesom sognet mange steder stadig er den naturlige enhed for lokalsamfundets foreningsliv m.v. (Andersen 2008, 7)

Sognet præsenteres her af forskere inden for geografi og geologi, som en enhed for både folkekirke og samfund. Og her både for civilsamfundet, som forenings- og kulturliv, og for de politiske dimensioner i relation til det nationale, det regionale og det lokalpolitiske niveau. Disse grænser er civilregistreringsgrænser, kommunegrænser, skolegrænser og identitetsgrænser på forskellig vis.

Samtidig er det kommunale niveau sekulært og uden formelle bånd til den lokale folkekirke. Hverken præster, menighedsråd eller biskopper har særlige krav på politisk indflydelse i en udvikling, der siden indførslen af grundloven og $i$ den løbende opdatering af lovgivningen har løst f.eks. de civile rettigheder fra bestemte religiøse sammenhænge og løst kirken som institution fra den lokale, politiske ledelse, hvor præster f.eks. ikke har særlige, fødte poster i den kommunale forvaltning. Man kan således sige, at sognekortet på mange måder stadigvæk ligger under det sekulære kommunekort, men at der er sket store forandringer i, hvordan det sekulære, kommunale niveau interagerer med folkekirken som institution. Dette er baggrunden for analysen af, hvornår folkekirkens interesser tilgodeses og hvornår de ikke gør på kommunalt niveau.

\section{Kommuner og kirkebygninger}

Kommunerne er i kontakt med folkekirken på forskellige måder. Kommunerne er en del af det politiske administrative system, som garanterer folkekirkens særstatus i forhold til opkrævning af kirkeskat. Den lokale kirkeskat fastsæxttes på provstiniveau og inddrives på samme måde som den øvrige nationale og kommunale skat. Alle sogne $\mathrm{i}$ en kommune har samme kirkeskatteprocent, men denne kan variere fra kommune til kommune. Her er kommunen primært administrativ, strukturel enhed for folkekirken, idet det er folkekirken selv, der fastsætter skatteprocenten i relation til primært provstiniveauet og kirkeministerniveauet. ${ }^{3}$ Der er således ikke tale om afgørelser, som kommunen har indflydelse på. Dette gælder til gengæld for det felt, hvorfra eksemplerne i denne artikel er taget, nemlig forvaltningen af de former for beskyttelse, som folkekirkens kirkebygninger falder ind under: kirkeindsigten, kirkebyggelinjen og til dels kirkeomgivelsesfredningen. 
Når det gælder den såkaldte kirkeindsigt, er det kommunerne, der varetager dette via kommuneplanen. Kommunerne har ifølge planloven pligt til at udarbejde en kommunalplan og herunder hører: „sikring af kulturhistoriske bevaringsværdier, herunder beliggenheden af værdifulde kulturmiljøer og andre væsentlige kulturhistoriske bevaringsværdier" (Planlovens kap. 4, $\$ 11$ a, stk. 15). I planloven nævnes kirker ikke specifikt, men de hører til de kulturhistoriske bevaringsværdier. Kommunerne fik ansvaret for kulturarven i forbindelse med kommunalreformen i 2007. I Aarhus Kommunes kommuneplan for 2013 er dette formuleret som følger:

\section{Kirkerne er de mindre bysamfund og lands- byernes vigtigste kulturhistoriske monument, og er oftest et markant kendingsmærke i landskabet. I kommuneplanen er der udpe- get kirkeindsigtsområder, der har til formål at sikre, at denne funktion ikke sløres eller forringes. (Aarhus Kommuneplan 2013, 83)}

De øvrige beskyttelser af kirkens bygninger nævnes også: „Kommuneplanens udpegning af kirkeindsigtsområder ændrer ikke ved eksisterende beskyttelsesbestemmelser i henhold til naturbeskyttelseslovens kirkebyggelinje og konkrete kirkeomgivelsesfredninger (de såkaldte provst Exner-fredninger).“ (Aarhus Kommuneplan 2013, 84). ${ }^{4}$ Kirkeindsigtsafsnittet i denne kommuneplan er en del af afsnittet om kulturmiljøer. Teksten ledsages af to billeder: et af Aarhus Universitets bygninger og et af en gammel, hvidkalket folkekirke.

Alle kommuner udarbejder sådanne kommuneplaner, og der er således på det generelle kommunale plan indarbejdet en ramme for håndteringen af kirkebygninger, som en del af kulturlandskabet. Der er endnu et vigtigt aspekt ved planloven, som den generelle gældende lov bag disse planer, som er relevant i forhold til denne artikel. Det drejer sig om spørgsmålet om, hvilke aktører der skal inddrages i beslutningsprocessen, og hvilke myndigheder der har ret til at gøre indsigelser, som skal indarbejdes (planlovens $₫ 28$ ). Dette bliver relevant i forhold til spørgsmålet om, hvorvidt folkekirken har status som en sådan myndighed, og også det bredere spørgsmål om, hvorvidt man i praksis giver folkekirken en sådan status, også der hvor det ikke formelt lovmæssigt er en ret folkekirken har. Eller om folkekirken primært ses som en del af det generelle civilsamfund, som kan indgive høringssvar, men som kommunen ikke selv ser som en nødvendig samtalepartner i processen.

I forhold til den anden form for beskyttelse, kirkebyggelinjen, er det muligt konkret at undersøge, hvordan sagerne håndteres. Kirkebyggelinjen reguleres efter natio- nal lovgivning, og kommunernes rolle er at administrere mulighederne for dispensation og har følgende formål:

For at forhindre, at der opføres bebyggelse, som virker skæmmende på kirkerne eller hindrer, at kirkerne er synlige i landskabet, er det inden for 300 meter fra en kirke forbudt at opføre bebyggelse, som er over 8,5 meter høj. I tilfælde, hvor kirken er omgivet af bymæssig bebyggelse i hele beskyttelseszonen, gælder forbuddet dog ikke. Bestemmelsen omfatter alt byggeri, men vil især have betydning for placering af siloer, elmaster og vindmøller. Kommunen træffer afgørelse om dispensation fra kirkebyggelinjen. (Naturstyrelsen, kirkebyggelinjen)

Dette forbud er baseret i naturbeskyttelseslovens $\$ 19$. Kirkebyggelinjen er indført i 1983 og er en ud af flere former for beskyttelseslinjer, som skal respekteres i forhold til nye byggerier og omlægning af lokalplaner i det, der betegnes 'åbent land' (såsom fortidsmindebeskyttelseslinjen og sø- og åbeskyttelseslinjen). Dette er således sat ind $\mathrm{i}$ en bred ramme af beskyttelse af centrale elementer i det danske kulturlandskab.

Kommunen kan give dispensation fra reglerne, hvis det skønnes, at et byggeri ikke vil skæmme kigget ind eller ud fra kirken, selvom det eventuelt ligger tættere på eller er højere end tilladt i de almene regler. Dette betyder, at kommunen skal udføre konkrete skøn ved hvert enkelt tilfælde. Som eksempel på forvaltningen af dette vil en sag fra Viborg Kommune blive inddraget. Sagen er valgt, fordi den også indeholder spørgsmålet om aktørniveauet på folkekirkens side, og fordi den indeholder aspekter af lokalplansdimensionen. I lokalplansprocessen fra $2010 \mathrm{i}$ Viborg Kommune anføres det, at man har haft planen i offentlig høring og har modtaget diverse svar, heriblandt fra Viborg Stift:

Høringssvar nr. 1 er fra Viborg Stiftsøvrighed, som er en myndighed, jf. planlovens $\S 28$. Stiftsøvrigheden har dog præciseret 31/8, at de ikke har bemærkninger til den konkrete lokalplan, men alene til procedure ved dispensation fra kirkebyggelinje. (Viborg Kommune, lokalplanshøring 2010).

I dette tilfælde kategoriseres stiftet klart som en myndighed, som har en bestemt lovmæssig status, jf. planloven. Samtidig viser det sig også, at stiftet primært er interesseret i fremover at være inddraget netop i spørgsmål om dispensation fra kirkebyggelinjen: „1) [Stiftet] 
ønsker en generel ændring af Viborg Kommunes procedure, så de bliver hørt inden Viborg Kommune meddeler dispensation fra kirkebyggelinjer. De oplyser, at denne procedure anvendes i andre kommuner." Kommunens forvaltning har svaret på dette og understreger her deres kompetence på området:

Forvaltningen har præciseret over for Viborg Stiftsøvrighed, at der ikke er ændringer af lokalplan 376 i forhold til den tidligere lokalplan 76A på dette punkt. Viborg Kommune har ifølge naturbeskyttelseslovens $\S 19$ myndighedskompetencen til at træffe afgørelser ift kirkebyggelinjen. Viborg Kommune har ikke pligt til at høre Stiftsøvrigheden, inden der træffes afgørelse, og har hidtil kun gjort det i relevante sager. På baggrund af Stiftsøvrighedens ønske har forvaltningen ændret denne procedure, så Viborg Kommune fremover altid hører Stiftsøvrigheden, inden der meddeles dispensation fra kirkebyggelinje. Det vurderes i omfang at være 3-4 sager om året. (Viborg Kommune, lokalplanshøring 2010).

Det vil sige, at den kommunale administration i dette papir, som skal vejlede den politiske beslutningsproces, anbefaler, at man ændrer i de konkrete procedurer, så stiftet vil blive inddraget $\mathrm{i}$ alle sager, der berører kirkebyggelinjen. Udvalget fulgte op på denne indstilling, således at proceduren nu indbefatter høring hos stiftet. ${ }^{5}$ Der er således tale om, at kirken går fra at kunne deltage i den almindelige høringsproces til at blive inddraget på særlig vis, før kommunen tildeler dispensation. Her tager folkekirken form som en konkret institution, som der tages særlige hensyn til igennem fast inddragelse af stiftsniveauet.

De følgende tre cases er eksempler på konflikter omkring kommunale afgørelser af dispensation fra kirkebyggelinjen. Alle tre sager er klager til Natur- og Miljøklagenævnet (NMK), som er den nationale instans for disse sager. Der er tale om klagesager fra perioden 2011-2013, hvor der ud af 687 sager i perioden kun er tre, der handler om kirkebyggelinjer.

\section{Case 1: Husstandsvindmølle inden for kirkebyggelinjen, Gribskov Kommune (NMK 2012)}

Gribskov Kommune har i første omgang givet dispensation til at opføre en husstandsvindmølle inden for kirkebyggelinjen ved Villingerød Kirke. Men denne kommunale afgørelse er blevet indklaget til nævnet af
Stiftsøvrigheden ved Helsingør Stift, hvor Villingerød Kirke ligger. Denne klage er baseret i to punkter: For det første, at stiftet ikke mener, det er begrundet, hvorfor vindmøllen er nødvendig, og for det andet, at kommunen ikke har hørt stiftet i sagen. Der er indhentet en vurdering fra arkitekter:

Villingerød Kirkeby udgøres af ganske få ejendomme, som ligger på et næsten fladt terræn. Oplevelsen af bebyggelsen forstærkes af træbeplantningen omkring husene, og overgangen mellem bebyggelse og landskab opleves ganske klar. Landsbyens bygningsmæssige hierarki domineres af kirken og skolen, der er identitetsskabende for bymiljøet. Den planlagte opstilling af en vindmølle vil fra nord opleves som et afvigende element, der ikke understøtter førnævnte kvaliteter. (NMK 2012, 1)

Gribskov Kommune gør rede for, hvorfor de har givet dispensation:

Kommunen vurderer, at møllen ikke medfører nogen skæmmende påvirkning af kirkens omgivelser. Baggrunden for denne vurdering er, at møllen tænkes opført nord for Villingerød Kirke. Mellem kirken og møllen ligger dels den gamle skole, der med sin høje rejsning har en højde på mere end 7 meter. Herudover er ansøgers hus i 11/2 plan med høj rejsning. Dermed vil møllen knapt kunne ses fra kirken. Set nordfra mod kirken vil den ikke stå som en skæmmende indretning i landskabet, men vil opleves som en del af landbrugsejendommen. (NMK, 2012, 2).

Her bliver det klart, at når kirkebyggelinjen forvaltes kommunalt, er det både indsynet og udsynet, der lægges vægt på, og at der er tale om en konkret vurdering af de lokale forhold, som afhænger af en fortolkning af, hvornår noget skæmmer eller er afvigende fra den generelle identitet som et kulturlandskab kan have. Konfronteret med klagen fra stiftet understreger kommunen sin interesse $\mathrm{i}$ at understøtte bæredygtige energiformer. Til spørgsmålet om stiftets rolle i processen siges det:

Kommunen bemærker til klagen over, at stiftsmyndigheden ikke er blevet hørt, før kommunen traf sin afgørelse, at det alene er ved dispensationer fra skovbyggelinjen, at loven stiller krav om høring af den pågæl- 
dende skovejer. Kommunen er af den opfattelse, at en høring af stiftsmyndigheden i forbindelse med dispensation fra kirkebyggelinjen reelt er overflødig. (NMK, 2012, 2)

Kommunen fremhæver således et miljøhensyn, og at den ikke er pålagt krav om at høre stiftet i sager om kirkebyggelinjen. Kommunen afviser, at folkekirken som institution er en nødvendig samarbejdspartner i disse sager, og ser i stedet forvaltningen af disse beskyttelseshensyn som en sag mellem kommunen og den borger, som har en byggesag. Kommunen forvalter en generel lov, og er ikke bundet til at interagere med stiftet eller andre dele af folkekirken.

I klagenævnets behandling af sagen støttes kommunens generelle håndtering af landzonelovgivningen, men ikke vurderingen af den konkrete sag i forhold til kirkebyggelinjen:

Nævnet finder, at navnlig møllens placering i området „Ådalen“, der er et område med landskabelige og kulturhistoriske værdier, som generelt er upåvirket af større tekniske anlæg og bymæssig bebyggelse, bør tillægges stor betydning. [...] Endvidere opstilles masten inden for kirkebyggelinjen. Kirken ligger i Villingerød Kirkeby, som udgøres af ganske få ejendomme, som ligger på et næsten fladt terræn, hvor overgangen mellem bebyggelse og landskab opleves ganske klar. Den planlagte opstilling af en vindmølle vil fra nord opleves meget synlig. Nævnet finder det hensigtsmæssigt, om stiftsmyndigheden havde været orienteret om ansøgningen, forinden kommunen traf sin afgørelse, uanset at dette ikke er et krav ifølge naturbeskyttelsesloven. (NMK, 2012, 3)

Nævnet er således uenig i den vurdering, som ligger til grund for kommunens beslutning, og underkender, at eventuelle miljøhensyn skulle kunne sætte kirkebyggelinjen ud af spillet. Området er af landskabelig og kulturhistorisk værdi, og det vil blive ødelagt af vindmøllen. Derudover fremhæver nævnet, at stiftet bør inddrages, selvom det ikke er et lovmæssigt krav.

\section{Case 2: Antennemast, Guldborgsund Kommune (NMK 2011a)}

I Guldborgsund Kommune finder vi en lignende sag, hvor der skal udskiftes en allerede eksisterende antennemast i landsbyen Eskilstrup. Kommunen har i første omgang tilladt udskiftningen af antennen:
Kommunen begrunder sin dispensation med, at det vurderes, at kirken ikke forringes som visuelt landskabselement, da antennemasten på 36 m, med et toprør på 3 m, erstatter en mast på 39 m. Kirken er i øvrigt omgivet af bymæssig bebyggelse, men ikke i hele beskyttelseszonen. Lolland Falster Stift har ikke haft indvendinger mod udskiftningen af masten. Masten er opstillet ca. $80 \mathrm{~m}$ fra kirkebygningen, på omtrent samme sted, hvor der tidligere har stået en antennemast fra 1974. Der er søgt om udskiftning af den eksisterende antennemast for at skabe bedre mobildækning, da statistiske beregninger har vist, at den tidligere mast ikke kunne bære det ekstra udstyr, der kræves for at etablere antennepositioner. (NMK 2011a, 1)

Her har kommunen truffet en afgørelse, det relevante stift har ikke haft noget imod udskiftningen. Det er i stedet Danmarks Naturfredningsforening, der har klaget over kommunens beslutning. Klagen går på, at der ikke reelt er tale om en udskiftning af en allerede eksisterende mast, men i stedet om opsættelsen af en meget større mobilmast, hvor der før var en TV-mast, og at den nye mast vil stå tættere på kirken end den tidligere og dermed være ødelæggende for kirkens placering i kulturlandskabet. Klagenævnet afviser klagen og opretholder kommunens beslutning om at give dispensation.

\section{Case 3: Antenne, Tønder Kommune (NMK 2011b)}

I den tredje sag er det også en antenne, som er stridens xble. Tønder Kommune har givet afslag på etableringen af en 21 meter høj gittermast med påførte antennesystemer til privat amatørradiokommunikation. Den person, som har ønsket at opføre antennerne, har klaget over afslaget og begrunder klagen både i, at der ikke er alternative steder at sætte antennen op og:

De ansøgte antenner vil ikke kunne ses fra kirken, da ejendommen [adresse3] ligger imellem og har en højde på mellem 16 meter og 22 meter. Klager er villig til at gå ned i højden og evt. ændre placeringen af masten til foran på huset, hvor den ikke vil være synlig fra [adresse4]. Her vil der være mellem 250 meter og 280 meter til kirken. (NMK 2011b, 1)

Nævnet redegør for forløbet og påpeger, at Ribe Stift har gjort indsigelse mod den ansøgte placering. (NMK 2011b, 1). Kommunens afgørelse stadfæstes af nævnet, og der er hermed ikke mulighed for at få dispensation til at opføre antennen.

Disse tre sager har flere interessante dimensioner i forhold til spørgsmålet om kommunalpolitik og folkekirke. 
For det første, at der tydeligvis er forskellig praksis, når det gælder inddragelse af folkekirken som aktør; hvor nogle kommuner hører det relevante stift, er der andre der holder på, at dette netop ikke er et krav og heller ikke for dem at se en nødvendighed. For det andet falder alle tre sager ud, så folkekirkens interesser tilgodeses. Dette gælder både, hvor de er i strid med kommunens og hvor de ikke er. For det tredje lægges der i alle afgørelser stor vægt på spørgsmålet om hvordan ind- og udsyn til kirken er i den lokale kontekst. De konkrete kirkebygninger tages alvorligt som dele af det kulturlandskab, som det er kommunens opgave at værne om. Samtidig er der mange andre hensyn at tage for en kommune, som sagen om vindmøllen peger på.

Disse tre sager er naturligvis på ingen måde tilstrækkelige til at sige noget om, hvorvidt dette er gældende over længere tid. Og som antallet af klagesager viser, så er det typisk ikke kirkebyggelinjen, der fører til konflikt, men i stedet de øvrige begrænsninger på byggesager. Hvorfor situationen er sådan, kan der jo kun gisnes om, men ifølge en samtale med en kommunal forvaltningsperson inden for området skyldes det primært, at kommunerne allerede i udarbejdelsen af lokalplanerne sørger for, at diverse former for beskyttelse respekteres. Men det er alligevel interessant, at når sager fører til klager, får folkekirken medhold.

Som et sidste perspektiv på dette vil den særlige kirkefredning blive inddraget. Kirkefredning administreres på regionalt niveau via fredningsnævn og skal respekteres i forhold til lokalplaner og kommuneplaner. Kirkefredningssagerne involverer folkekirken direkte som aktør, da det f.eks. kan være et lokale menighedsråd, der gerne vil have lov til at opføre nye eller ændre på allerede eksisterende bygninger, men her får afslag fra de regionale fredningsnævn, og derefter kan klage til det samme nationale klagenævn, som tager sig af sagerne om kirkebyggelinjen. I den periode, hvor der er sager tilgængelige, har der været flere klagesager, som involverer folkekirken. I den almene praksis lægges der op til, at folkekirkens sogne inden for almindelige rammer kan få lov til at bygge og ændre på bygninger. Men der er sager, hvor der er konflikter mellem folkekirkens ønske om at bygge og fredningen af kirke og omgivelser. Dette gælder f.eks. i en sag fra Helsingør Kommune, hvor det regionale nævn har givet dispensation til at opføre et sognehus ved Hellebæk Kirke (NMK 2011c). Danmarks Naturfredningsforening har dernæst klaget over denne dispensation. Klagen er motiveret i, at „indsynet til kirken vil blive indskrænket, at sognehuset henset til dens størrelse vil blive en alvorlig konkurrent til den lille og meget helstøbte kirke“, og at fredningen er „begrænset til én ejendom“ (NMK 2011c, 2).
Menighedsrådet har oprindeligt ansøgt om byggetilladelse, fordi det fremhæver behovet for lokaler, som kan bruges til menighedens aktiviteter, kontor til ansatte og andre nødvendige faciliteter til „kirkens betjening af menigheden" (NMK 2011c, 2). Det regionale nævn, som gav dispensation, lagde vægt på, hvordan man generelt giver tilladelse til, at menighedsråd kan opføre bygninger og lave ændringer inden for fredede områder, og: „At den for ejendommen gældende fredning har til formål at sikre at kirkens omgivelser kommer til at fremtræde så smukt og værdigt som muligt, specielt således at skæmmende bebyggelser ikke anbringes så tæt på kirken at skønhedsværdier går tabt eller kirkens interesser krænkes“ (NMK 2011c, 3).

Dette var ifølge det regionale nævn opfyldt, og der blev givet dispensation på baggrund af, at byggeriet var til et velbegrundet kirkeligt formål. Beslutningen blev taget på baggrund af en afstemning, hvor et større mindretal mente, at denne sognegård var for stor i forhold til kirken.

Klagen fra Danmarks Naturfredningsforening til det nationale nævn går på, at denne konkrete kirkebygning ligger højt med indsyn, som en helstøbt bygning, som „bør forblive uberørt på sin fritliggende, majestætiske placering højt over Øresund“. Og nævner baggrunden for fredningsreglerne, nemlig hvordan de såkaldte Provst Exner-fredninger kom til for at beskytte disse bygninger i landskabet (NMK 2011c, 4).

Menighedsrådet er ikke enig i denne udlægning. Det fremhæver, at Exners tanker om fredning netop handlede om at beskytte kirken mod skæmmende bygninger, og „aldrig har haft til hensigt at fungere som benspænd for kirkens egen udfoldelse"(NMK 2011c, 5). Klageinstansen giver klager medhold, og sognehuset kan ikke opføres som planlagt.

I en anden sag om en sognebygning ved Bording Kirke har menighedsrådet i første omgang fået afslag på en dispensation fra fredningsreglerne. Dette har menighedsrådet klaget over ud fra behov for tidssvarende bygninger med handicaptilgang og plads til medarbejderne og rammer for en kirke, der er velbesøgt. Her er kommune og kirke på samme side, men afvises af det regionale råd:

Klager har endvidere henvist til, at kommunen og Viborg Stift har støttet ansøgningen, og at menighedsrådet støtter landskabsarkitektens vurdering af, at det er en ideel placering. Bebyggelsen vil afslutte byens bebyggelse på fin vis op mod kirken, mens udsigten til de omkringliggende smukke omgivelser og åbne landskaber vil blive tilgodeset. (NMK 2008, 2) 
Men klagenævnet fastholdte fredningsnævnets beslutning, og det planlagte sognehus kan ikke opføres. I disse to sager inden for fredningslovgivningen er der altså i begge sager givet afslag på at bygge nye sognegårde ud fra argumentationer om placeringen i kulturlandskabet. Der er således i denne del af fredningsmaterialet en tendens til at nævnet går imod folkekirkens ønske om at opføre egne nye bygninger. I stedet tilgodeses klager fra f.eks. Danmarks Naturfredningsforening.

\section{Kirkeindsigt på kommunalt niveau}

De forskellige cases peger på, at folkekirken på den ene side har privilegier, som gør den anderledes end de øvrige trossamfund, her de særlige beskyttelser af en række kirkebygninger. Men på den anden side også, at folkekirken ikke nødvendigvis kan være sikker på at drage fordel af denne nærhed til kommunale, regionale og statslige niveauer af politik og administration. Det er ikke folkekirkens selvforståelse eller behov som står i første række. Eller sagt på en anden måde, det primære system, som der forvaltes ud fra, er baseret i en sekulær logik, som handler om bevarelse af kulturlandskabet. Hvor folkekirken fik medhold i sit synspunkt i alle klagesager over kirkebyggelinjen, er der ikke støtte til de større byggeprojekter i forhold til kirkeomgivelsesfredningen. Folkekirken har, sat lidt på spidsen og udelukkende med udgangspunkt i disse sager, således lettere ved at forhindre opførslen af andres bygninger end at få lov til selv at bygge nyt. Dette antyder, at når kirkens behov passer ind $\mathrm{i}$ bevarelsen af kulturlandskabet, som det forstås og forvaltes kommunalt og af diverse nævn, så er den offentlige forvaltning en stærk samarbejdspartner, men hvis kirken har projekter, som ikke er i tråd med dette, er kommuner og nævn ikke nødvendigvis på folkekirkens side. Når kirken er med til at bevare, går sagerne til kirkens fordel, men når kirken ønsker at forandre, er dette ikke nødvendigvis tilfældet. Dette peger på, hvordan studier af det lokale, kommunale niveau bidrager med nogle nødvendige nuancer af, hvad forholdet er mellem religion og politik i Danmark i dag. Ud fra et governance-perspektiv vil man således kunne fremhæve, at også denne religiøse institution bliver formet i et møde med offentlige myndigheder og samfundsinstanser, som opererer ud fra andre logikker end dem, der eventuelt er på dagsordenen internt i det specifikke trossamfund. Folkekirken er således i disse sager et trossamfund, som skal navigere i det offentlige system som alle andre. Folkekirken må lokalt og regionalt via me- nighedsråd og stiftsniveau arbejde aktivt for at blive inddraget i proceduren f.eks. som faste samarbejdspartnere i sager om dispensation fra kirkebyggelinjen.

Beskyttelsen af kirkens bygninger, som en del af kulturlandskabet, kan ikke udelukkende siges at være et privilegium, som folkekirken nyder godt af. Billedet er mere kompliceret, når man går ned i den reelle sagsgang i udvalg, nævn og klageinstanser. Her tegner der sig i stedet et billede af, hvordan myndighederne primært står som garanter for kirkebygningen i det fælles kulturlandskab, og hvor også lokale sognekirker kan tabe kampen om at forme de rum, de ønsker til udfoldelse af deres religiøse fællesskab. De beskyttelsesforanstaltninger, der er på plads, er ikke motiveret ud fra en støtte til et trossamfund som sådan, men motiveret ud fra den kulturelle værdi kirkens bygninger og placering har for samfundet generelt. Beskyttelsen er således af alle borgeres fælles kulturelle værdier og forvaltes ikke grundlæggende som en beskyttelse af en bestemt religiøs gruppes interesser.

Når man vender blikket mod det lokale, kommunale niveau, får man et indblik $\mathrm{i}$, at der her er en forvaltningsmæssig hverdag langt fra de store landspolitiske, debatskabende overskrifter om danske værdier og kristendommens rolle. Her på det lokale niveau forvaltes en bestemt dimension af folkekirkens privilegier, som ikke ofte er til debat. Her er aktører i kommune og kirke i tæt kontakt, og somme tider i konflikt, omkring håndtering af de love, som fremhæver, at folkekirkens kirker primært er en del af det fælles danske kultur- og naturlandskab. Der tales ikke om religion specifikt og der nævnes ikke specifikke sammenhænge med f.eks. evangelisk-luthersk kristendom eller andre af de værdimarkeringer, som betyder noget for kirkens selvforståelse. Det er tale om en mere stille og ubemærket aktivitet, som ikke desto mindre peger på, at der på kommunalt niveau foreligger en tilgang til de kirkelige bygninger og institutioner, som primært er styret af et ønske om at bevare generelle kulturelle værdier på alle borgeres vegne. Og denne værdi skal beskyttes både mod afvigende antenner og afgivende sognehuse. Det kan i forlængelse af denne artikel derfor overvejes, om den lokale praksis i håndtering af disse sager på sigt kan være med til at påvirke mere overordnede niveauer af forholdet mellem stat og kirke, f.eks. i den måde folkekirkens egne aktører bliver nødt til mere formelt at etablere aftaler om indflydelse og dermed finde deres plads i den kommunale logik. 


\section{Referencer}

Andersen, HT; Engelstoft, S; Winther, L 2008, 'Analytisk operationalisering af bylandskabstanken Notat udarbejdet for By-og Landskabsstyrelsen, Miljoministeriet', TAPAS Working Paper 2008:01 Institut for Geografi \& Geologi, Københavns Universitet.

Bruce S 2002, God is dead: secularization in the West, Blackwell Publishers. Oxford, UK

Calhoun CJ 2011, Rethinking secularism, C. Calhoun, M Juergensmeyer \& J Van Antwerpen (eds.) Oxford University Press, Oxford.

Christensen, H R 2014 (under udgivelse), 'Secularism and Religious Authority: Mirror Images in Public Representations of Religion' in Journal of Contemporary Religion.

Clemmensen, N 2011, Konflikt og konsensus i kommunen: det landkommunale selvstyre i Danmark i det 19. århundrede, Museum Tusculanum, København

Dobbelaere K 1981 Secularization : a multi-dimensional concept . Serie: Current sociology ; Vol.29, no.2. Sage. Beverly Hills.

Knudsen, T 2003, 'De nordiske statskirker og velfærdsstaterne', i 13 historier om den danske velferdsstat, ed. Klaus Petersen, Syddansk Universitetsforlag, Odense.

Kühle, L 1999, 'Sekulariseringstesen i religionssociologien - reformulering eller paradigmeskift?', in Religionsvidenskabeligt Tidsskrift nr. 55, 45-60.

Kühle, L \& Nielsen MV 2011, 'Religion and State in Denmark: Exception among Exceptions?' Nordic Journal of Religion and Society, vol 24, nr. 2, 173-188.

Maussen, M 2006 The governance of Islam in Western Europe - A state of the art report, IMISCOE Working Paper No. 16.

Naturstyrelsen, kirkebyggelinjen: http://naturstyrelsen.dk/planlaegning/planlaegning-i-det-aabne-land/bygge-og-beskyttelseslinjer/ kirkebyggelinjen/

NMK 2008: Bording Kirke, afgørelse af 30. oktober 2008: (Sag NKN121-00121)

NMK 2011a: Case 2: Guldborgsund Kommune. 30.06.2011. (NMK504-00001)
NMK 2011b: Case 3. Tønder Kommune. 26.09.2011. (Sag NMK-50400002)

NMK 2011c: Hellebæk Kirke, afgørelse af 21. oktober 2011 (Sag NMK522-00046)

NMK2012: Case 1 Gribskov Kommune. 11.05.2012 (Sag NMK3100461

Planloven, Lov om planlægning af 27/05/2013

Sidenvall, E 2010 'A Classic Case of de-Christianisation? Religious Change in Scandinavia c. 1750- 2000' in Secularisation in the Christian World, Brown, CG; Snape, M (eds.). Ashgate Publishing Group, Farnham.

Torfing J, Peters GB, Pierre J, \& Sørensen E 2012, Interactive Governance: Advancing the Paradigm, Oxford University Press, Oxford.

Viborg Kommune, lokalplanshøringsproces 2010: http://dom.viborg. $\mathrm{dk} / \mathrm{db} /$ dagsord.nsf/69147069b83c7e5dc1256c54002e6773/269783 91a97799b0c12577b5004b9cc1/\$FILE/TU-061010-157-2.pdf

Østergaard, U 2003. 'Lutheranismen, danskheden og velfærdsstaten', i 13 historier om den danske velfardsstat, ed. Klaus Petersen, Syddansk Universitetsforlag, Odense.

Aarhus Kommuneplan 2013, http://www.aarhus.dk/da/borger/boligog-byggeri/kommuneplanlaegning/kommuneplan-2013.aspx

\section{Noter}

1. Kongehuset spiller også en formel rolle i forhold til styringen af kirken, idet det kongelige overhoved skal give kongelig resolution til bestemte beslutninger.

2. Der er fortsat efter 1933 forskellige former for gejstligt tilsyn, f.eks. på provstiniveau, som forsvinder i praksis i 1949.

3. I 2013 var den laveste kirkeskatteprocent 0,42 (Gentofte Kommune), mens den højeste var 1,48 (Samsø Kommune). http://www. km.dk/kirke/folkekirken/oekonomi/kirkeskat/

4. Provst Exner-fredninger, opkaldt efter Gustav Johan Adolf Exner, som fra slutningen af 1930'erne begyndte at indhente frivillige fredninger af kirkeomgivelser, som senere danner baggrund for fredningsregler for kirkeomgivelser.

5. Bekræftet pr. e-mail fra Viborg Kommune, 28. maj 2014. 